\title{
家畜の産子性比について ブタ (2)
}

\author{
西田司一・大塚順” ・斎藤馨 ${ }^{2}$ \\ (1)コッブ・ジャパン農場， ${ }^{21}$ 杤木県畜産試験場) \\ (1970.8. 5 受付)
}

著者ら（'69）はブタの産子性比第 1 報として，滝川蓄 試の資料について報告した。その際，バークシャ一喠の みが季節的に雌へかたより示し，これらの現象が品種 に特有なものかどうか興味をもった。全国的調査を企 画しているが，まず，この品種の多い㭏林省畜座試験場 (以下畜試)，鹿児島県養豚試験場（鹿児島）の資料を分 析した。なお，杤木県畜産試験場（杤木）の資料子入手 分析することができたので，今回は上記 3 試験場の資料 を滝川のものと比較して報告する。

\section{材料および方法}

今回の材料は, 畜試では 1917〜1966にわたる総子数 13, 085 頭, 品種はラージホァイト (W), ヨークシャー (Y), ランドレース (L), バークシャ一-(B), 中国種 (C), ポーランドチャイナ (P), これらの間の交雑種 (Hyb) で，交雑種の中に注少数のイノシシとの交雑種 が含ま机ている．鹿児島は 1952１968の 4, 538 頍， B，L抢よび Hyb であり，杤木は 1962〜1968の 2,882 頭， $\mathrm{Y} ， \mathrm{~L}$ の 2 品種で，全部人工授精である. 前報と同 様少数の不完全記録も含まれている. 調查項目, 性比表 示法拉よび統計好理は前報と同様である。今回は，デー タの表示は性比のかたよりを示与階級を主とした。

\section{結果}

1）総産子性比 (Table 1)：畜試, 栃木の各品種合計 (以下合計)の性比は，それぞれ $51.5 ， 52.7 \%$ で危 険率 $1 \%$ （以下 1\%）で雄へかたより示すが，鹿児島 はかたよりを示さない，品種別にみると，畜試では $\mathrm{Y}$, Bが雄へかたより，杤木ではY，Lが雄へかたよるが， 鹿児島ではかたよりを示す品種はない４場間の差をみ ると，合計，Yでは差はみられず，L(潼川一鹿児島), B (滝川一畜試, 鹿児島) に打いてのみ有意差認められ る.

2) 父，母ブタ個体別産子性比 (Table 2)：父，母ブ タともにその産子性比がかたよるものがある.品種别に

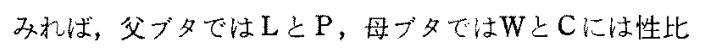
のかたよりを示す個体はない、性比のかたよりを示個 体の百分率をるると，母ブタでは4 場間に大差はない。 なお，これら個体の家系も調监したが，1 報と同様に結

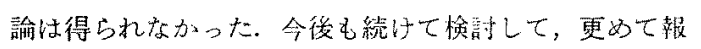
告したい.

3）産次別産子性比（Table 3)：畜試はかたよりを示 す産次数がやや少ないは加，滝川とよく似ている，4 つの産次は雄へかたよりを示す。鹿児島ではかたよりを 示可産次はなく，杤林で第 11 産次は雄へ，第 14 産次 は雌へかたよっている，産次を1報と同怺に区分する 上, 畜試では 3 産次以後, 杤木では 4 産次以後で雄入か たよるが，鹿児島ではかたよりはみられない，品種別に みると，W， L， C， P ではかたより宗可産次はな く，かたよりを示可産次数はY温を多い。また，Bも 畜試では第 3 産次で雄へかたよるが，鹿児島ではかたよ りはみられない。

4) 同腹子数別産子性比 (Table 4)：合計，品種別い ずれにおいても，性比のかたよりを示方階級数は滝川に くらべ少なく、ほ上えどが雄へかたよっている，合計 で，畜誠の子数20でのみ雔へかたよるが，これはWで みられたものである. 鹿児島では，品種别にみると Bと Hyb 雄八がたよる階級があるが，合計ではこれらは かくされ，子数1で斟へかたよりがみられる。杤木で は，合計の 2 階級で雄へかたよっているが，これらはる れぞれYとLによるものである.そのほかに，Lの子数

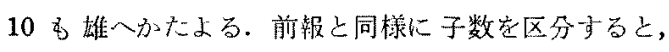
甾試は滝川とよく似ている。杤木では 1 5，11〜15の 両区で雄へかたよるが，㫣児島ではかたよりは马られな w.

5) 李節別産子性比 (Table 5): 合計に标いて, 畜 試，杤木では一，二次ともに雄へかたよりを示可季節か あるが，鹿児島では一，二次性比ともにかたよりは好ら れない, 品種別以みると，Bにおいて子，音試では冬 (二次)，秋 (一次), 鹿児島では秋（一次）に雄八かた 
西田・大缘・斎滕

Table 1. Sex ratio of offspring

Table 1-1. Sex ratio in total and each groupat National Institute, Kagoshima and Tochigi experimental station

\begin{tabular}{|c|c|c|c|c|c|c|c|c|c|}
\hline \multirow{2}{*}{ Breed } & \multicolumn{3}{|c|}{ NI } & \multicolumn{3}{|c|}{$\mathrm{Ks}$} & \multicolumn{3}{|c|}{ To } \\
\hline & $\hat{\delta}$ & $\hat{\delta}+$ 우 & $\widehat{\delta} \%$ & $\delta$ & $\hat{8}+q$ & 今 $\%$ & $\hat{\delta}$ & $\hat{\delta}+q$ & $\beta \%$ \\
\hline W & 433 & 868 & 49.9 & & & & & & \\
\hline $\mathrm{Y}$ & 3,694 & 7,224 & $51.1^{* *}$ & & & & 1,150 & 2,149 & $52.4 *$ \\
\hline $\mathrm{L}$ & 50 & 97 & 51.5 & 618 & 1,215 & 50.9 & 370 & 688 & $53.8^{*}$ \\
\hline \multicolumn{10}{|l|}{$\mathbf{H}$} \\
\hline B & 916 & 1,739 & $52.7^{*}$ & 1,505 & 2,952 & 51.0 & & & \\
\hline$c$ & 81 & 142 & 57.0 & & & & & & \\
\hline $\mathbf{P}$ & 494 & 946 & 52.2 & & & & & & \\
\hline Hyb & 1,042 & 2.013 & 51.8 & 188 & 371 & 50.7 & & & \\
\hline Unknown & 25 & 56 & 44.6 & & & & & & \\
\hline Total & 6,735 & 13,085 & $51.5^{* *}$ & 2,311 & 4,538 & 50.9 & 1,520 & 2,882 & $52.7^{* *}$ \\
\hline
\end{tabular}

Table 1-2. Difference in sex ratio among four experiment stations

\begin{tabular}{|c|c|c|c|c|c|c|c|c|c|c|}
\hline & \multicolumn{4}{|c|}{ Total } & \multicolumn{4}{|c|}{ L } & & \\
\hline & $\mathrm{Ta}$ & $\mathrm{NI}$ & $\mathrm{Ks}$ & To & $\mathrm{Ta}$ & NI & Ks & To & & \\
\hline $\mathrm{Ta}$ & - & is & is & is & 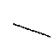 & is & $* *$ & is & & \\
\hline NI & is & & is & is & $* *$ & & is & is & & \\
\hline $\mathrm{Ks}$ & - & - & & is & * & is & & is & $\begin{array}{l}\text { In all tables: } \\
\text { Ta } \cdots \text { Takikawa }\end{array}$ & is $\cdots$ insignificant \\
\hline To & is & is & - & & - & - & - & & $\begin{array}{l}\text { NI } \cdots \text { National Institute } \\
\text { K } \cdots \text { Kagoshima } \\
\text { To } \cdots \text { Tochigi }\end{array}$ & $\begin{array}{l}* . . . \text { significant at a } 0.05 \text { level } \\
* * \ldots \text { significant at a } 0.01 \text { level }\end{array}$ \\
\hline
\end{tabular}

Table 2. Boars and sows showing high or low sex ratios

Table 2-1. Number of boars and sows

\begin{tabular}{|c|c|c|c|c|c|c|c|c|c|c|c|}
\hline \multirow{3}{*}{ Breed } & \multirow{3}{*}{$\begin{array}{l}\text { Exp. } \\
\text { station }\end{array}$} & \multicolumn{5}{|c|}{ Boar (NI, 197; $\mathrm{K}_{\mathrm{s}}, 42 ; \mathrm{To}, 18$ in total) } & \multicolumn{5}{|c|}{ Sow (NI, 464; $\mathrm{K}_{\mathrm{s}}, 158$; To, 94 in total) } \\
\hline & & \multicolumn{2}{|c|}{ High } & \multicolumn{2}{|c|}{ Low } & \multirow{2}{*}{ Total } & \multicolumn{2}{|c|}{ High } & \multicolumn{2}{|c|}{ Low } & \multirow{2}{*}{ Total } \\
\hline & & $\$ 0.05$ & 0.01 & 0.05 & 0.01 & & 0.05 & 0.01 & 0.05 & 0.01 & \\
\hline W & NI & & & & 1 & 1 & & & & & \\
\hline $\mathbf{Y}$ & $\begin{array}{l}\text { NI } \\
\text { To }\end{array}$ & $\begin{array}{l}2 \\
1\end{array}$ & $\begin{array}{l}1 \\
0\end{array}$ & $\begin{array}{l}3 \\
1\end{array}$ & $\begin{array}{l}0 \\
0\end{array}$ & $\begin{array}{l}6 \\
2\end{array}$ & $\begin{array}{l}7 \\
3\end{array}$ & $\begin{array}{l}4 \\
0\end{array}$ & $\begin{array}{l}6 \\
1\end{array}$ & $\begin{array}{l}1 \\
0\end{array}$ & $\begin{array}{r}18 \\
4\end{array}$ \\
\hline $\mathrm{L}$ & $\begin{array}{l}\mathrm{Ks} \\
\mathrm{To}\end{array}$ & & & & & & $\begin{array}{l}1 \\
0\end{array}$ & $\begin{array}{l}0 \\
0\end{array}$ & $\begin{array}{l}0 \\
1\end{array}$ & $\begin{array}{l}0 \\
0\end{array}$ & $\begin{array}{l}1 \\
1\end{array}$ \\
\hline $\mathbf{B}$ & $\begin{array}{l}\mathrm{NI} \\
\mathrm{Ks}\end{array}$ & $\begin{array}{l}2 \\
0\end{array}$ & $\begin{array}{l}2 \\
0\end{array}$ & $\begin{array}{l}0 \\
1\end{array}$ & $\begin{array}{l}1 \\
0\end{array}$ & $\begin{array}{l}5 \\
1\end{array}$ & $\begin{array}{l}2 \\
3\end{array}$ & $\begin{array}{l}2 \\
2\end{array}$ & $\begin{array}{l}4 \\
3\end{array}$ & $\begin{array}{l}0 \\
0\end{array}$ & $\begin{array}{l}8 \\
8\end{array}$ \\
\hline $\mathrm{C}$ & NI & 1 & 0 & 0 & 0 & 1 & & & & & \\
\hline $\mathbf{P}$ & $\mathrm{NI}$ & & & & & & 2 & 0 & 0 & 0 & 2 \\
\hline Hyb & NI & 4 & 0 & 0 & 0 & 4 & 1 & 0 & 2 & 0 & 3 \\
\hline
\end{tabular}

Table 2-2. Percentage of boars and sows

\begin{tabular}{llllllllllll}
\hline NI & 4.7 & 1.5 & 1.5 & 1.0 & 8.6 & 2.6 & 1.2 & 2.6 & 0.2 & 6.7 \\
Ks & 0.0 & 0.0 & 2.4 & 0.0 & 2.4 & 2.6 & 1.3 & 2.0 & 0.0 & 5.9 \\
To & 5.6 & 0.0 & 5.6 & 0.0 & 11.1 & 3.2 & 0.0 & 2.1 & 0.0 & 5.3 \\
\hline
\end{tabular}

\#...Significance level 
Table 3. Litter series and sex ratio

Table 3-1. Total of all groups of breed

\begin{tabular}{|c|c|c|c|c|}
\hline \multirow{2}{*}{$\begin{array}{l}\text { Litter } \\
\text { series }\end{array}$} & \multicolumn{2}{|c|}{ NI } & \multicolumn{2}{|c|}{ To } \\
\hline & s+o & 需\% & \$干+우 & $\widehat{\partial} \%$ \\
\hline 3 & 1,971 & $53.3^{* *}$ & & \\
\hline 4 & 1,446 & $53.0^{*}$ & & \\
\hline 6 & 713 & $55.8^{* *}$ & & \\
\hline 8 & 349 & $55.3^{*}$ & & \\
\hline 11 & & & 56 & $64.3^{*}$ \\
\hline 14 & & & 22 & $36.4^{* * *}$ \\
\hline
\end{tabular}

Table 3-2. Grouping of litter series in total groups of breed

\begin{tabular}{|c|c|c|c|c|c|c|}
\hline \multirow{2}{*}{$\begin{array}{l}\text { Group- } \\
\text { ing }\end{array}$} & \multicolumn{2}{|c|}{ NI } & \multicolumn{2}{|c|}{ Ks } & \multicolumn{2}{|c|}{ To } \\
\hline & $8+0$ & 今\% & $\hat{\delta}+q$ & $\delta \%$ & $3+9$ & $5 \%$ \\
\hline $3 \sim 4$ & 3,417 & 53. $2^{* *}$ & 1,151 & 50.5 & 801 & 52.6 \\
\hline $5 \sim 7$ & 2,152 & $52.5^{*}$ & 1,212 & 50.3 & 750 & 52.3 \\
\hline $8 \sim$ & 1,123 & $54.0^{* *}$ & 560 & 53.8 & 405 & $55.6^{*}$ \\
\hline $4 \sim$ & 4,721 & $53.0^{* *}$ & 2,306 & 51.0 & 1,527 & $53.8 * *$ \\
\hline $1 \sim 4$ & 9,340 & $51.1 *$ & 2,680 & 50.7 & 1,714 & $52.7^{*}$ \\
\hline $5 \sim$ & 3,275 & $53.0^{* *}$ & 1,772 & 51.4 & 1,155 & $53.4^{*}$ \\
\hline $1 \sim 5$ & 10,308 & $51.0^{*}$ & 3,170 & 50.9 & 2,047 & $52.6^{*}$ \\
\hline $6 \sim$ & 2,307 & $54.3^{* *}$ & 1,282 & 51.2 & 822 & $54.0^{*}$ \\
\hline
\end{tabular}

Table 3-3. Litter series showing high or low sex ratio in each group of breed

\begin{tabular}{|c|c|c|c|c|c|}
\hline & & \multicolumn{2}{|c|}{ NI } & \multicolumn{2}{|c|}{ To } \\
\hline & & $\# 0.05$ & $\overline{0.01}$ & 0.05 & 0.01 \\
\hline \multirow{2}{*}{$\mathbf{Y}$} & $\mathrm{h}$ & $6,8,9$ & & 2,11 & \\
\hline & 1 & & & & 14 \\
\hline \multirow{2}{*}{ B } & $\mathrm{h}$ & 3 & & & \\
\hline & 1 & & & & \\
\hline \multirow{2}{*}{ Hyb } & $\mathbf{h}$ & & 3 & & \\
\hline & 1 & & & & \\
\hline
\end{tabular}

h...... Higher than $50 \%$......Significance level

1...... Lower than $50 \%$

よりを示す。なお，今回の交配年月日注実際の記録に よった．季節性比間の差をみると，合計の二次性比では 3場ともに有意差は夕られないが，一次性比では杤木の 春と秋の間にの文有意差がみられる. 品種別に季節間の 差を及ると，二次で注畜斌のBで夏と冬の間に，一次で は鹿児島のB，Lで夏と冬の間，Lで秋と冬の間，栃木 のLで春と秋の閒に有意差が認められる(表は省略).

6）自然交配，人工授精之産子性比（Table 6)：皆児
Table 4. Litter size and sex ratio Table 4-1. Total of all groups of breed

\begin{tabular}{|c|c|c|c|c|c|c|}
\hline \multirow{2}{*}{$\begin{array}{c}\text { Litter } \\
\text { size }\end{array}$} & \multicolumn{2}{|c|}{ NI } & \multicolumn{2}{|c|}{$\mathrm{Ks}$} & \multicolumn{2}{|c|}{ To } \\
\hline & $8+9$ & $\widehat{3} \%$ & $\widehat{6+q}$ & $\delta \%$ & $\widehat{0}+q$ & 今 $\%$ \\
\hline 1 & & & 21 & $28.6^{*}$ & & \\
\hline 5 & & & & & 70 & $62.9 *$ \\
\hline 10 & 1,980 & $52.4^{*}$ & & & & \\
\hline 12 & 1,248 & $54.7^{* *}$ & & & 432 & $56.3^{\text {*** }}$ \\
\hline 20 & 20 & $20.0^{* *}$ & & & & \\
\hline
\end{tabular}

Table 4-2. Grouping of litter size in total of all groups of breed

\begin{tabular}{rrrrrrr}
\hline \hline $1 \sim 5$ & 1,227 & 50.8 & 460 & 52.0 & 145 & $58.2^{*}$ \\
$6 \sim 10$ & 7,675 & $51.2^{*}$ & 2,439 & 51.7 & 1,235 & 51.1 \\
$11 \sim 15$ & 4,139 & $52.6^{* *}$ & 1,481 & 49.3 & 1,330 & $53.8^{* *}$ \\
\hline
\end{tabular}

Table 4-3, Litter size showing high or low sex ratio in each group of breed

\begin{tabular}{|c|c|c|c|c|c|c|c|}
\hline \multirow{2}{*}{ Breed } & \multirow{2}{*}{$\begin{array}{c}\text { Sex } \\
\text { ratio }\end{array}$} & \multicolumn{2}{|c|}{$\underbrace{\text { NI }}$} & \multicolumn{2}{|c|}{$\underbrace{\mathbf{K s}}$} & \multicolumn{2}{|c|}{ To } \\
\hline & & 0.05 & 0.01 & 0.05 & 0.01 & 0.05 & 0.01 \\
\hline \multirow{2}{*}{ W } & h & & & & & & \\
\hline & 1 & & 20 & & & & \\
\hline \multirow{2}{*}{$Y$} & h & 10 & & & & 5 & \\
\hline & 1 & & & & & & \\
\hline \multirow{2}{*}{ L } & h & & & & & 10 & 12 \\
\hline & 1 & & & & & & \\
\hline \multirow{2}{*}{ B } & h & & & 10 & & & \\
\hline & 1 & & & & & & \\
\hline \multirow{2}{*}{ C } & $\mathrm{h}$ & 4 & & & & & \\
\hline & 1 & & & & & & \\
\hline \multirow[t]{2}{*}{$\mathrm{P}$} & $h$ & 12 & & & & & \\
\hline & 1 & & & & & & \\
\hline \multirow{2}{*}{$\mathrm{Hyb}$} & h & & & 11 & & & \\
\hline & 1 & & & & & & \\
\hline
\end{tabular}

Remarks..... See the footnote of table 3-3

島および栃木では，人工投精のみで比較材料艻ない。 畜試では，合計の自然交配，人工授精己もに雄へかたよ るが，それらの間に有意差はみられない，品種別にみる と，畜試の $\mathrm{Y}, \mathrm{Hyb}$ で有意差がみられる，Hyb では 自然交配，人工授精ともに廒于性比自身はかたよってい ない.

7) 父ブタ年令剧座子性比 (Table 7)：合計では，畜 試の3年令, 质木の 2 年令で雄へがよるが, 滝川にく 
Table 5. Season and sex ratio

Table 5-1. Sex ratio in each season in total of all groups of breed

Secondary sex ratio

\begin{tabular}{|c|c|c|c|c|c|c|c|c|}
\hline \multirow{2}{*}{ Exp. station } & \multicolumn{2}{|c|}{ Spr. } & \multicolumn{2}{|c|}{ Sum. } & \multicolumn{2}{|c|}{ Aut. } & \multicolumn{2}{|c|}{ Win. } \\
\hline & $8+q$ & $8 \%$ & $8+q$ & $\widehat{\delta} \%$ & 今t+웅 & $8 \%$ & $\delta+q$ & 今\% \\
\hline NI & 6,400 & 51.0 & 1,426 & 52.2 & 4,781 & $52.0^{* *}$ & 539 & 52.1 \\
\hline $\mathrm{Ks}$ & 1,485 & 51.0 & 830 & 51.4 & 1,325 & 50.1 & 893 & 51.5 \\
\hline To & 952 & $53.6^{*}$ & 708 & 49.6 & 534 & 53.7 & 685 & $54.3^{*}$ \\
\hline \multicolumn{9}{|c|}{ Primary sex ratio } \\
\hline NI & 2,241 & 51.0 & 3,583 & $52.1^{*}$ & 2,362 & 50.2 & 4,907 & $51.8^{*}$ \\
\hline $\mathrm{Ks}$ & 1,029 & 50.4 & 1,161 & 50.0 & 1,115 & 50.7 & 1,228 & 52.4 \\
\hline To & 612 & 49.5 & 567 & 54.0 & 852 & $54.7^{* *}$ & 848 & 52.5 \\
\hline
\end{tabular}

Table 5-2. Sex ratio in each season in each group of breed

\begin{tabular}{|c|c|c|c|c|c|c|c|}
\hline \multirow[b]{2}{*}{$\begin{array}{l}\text { Exp. } \\
\text { station }\end{array}$} & \multirow[b]{2}{*}{ Sex ratio } & \multicolumn{3}{|c|}{ Secondary sex ratio } & \multicolumn{3}{|c|}{ Primary sex ratio } \\
\hline & & $\mathrm{Y}$ & $\mathrm{L}$ & $\mathrm{B}$ & $\mathrm{Y}$ & $\mathrm{L}$ & $\mathrm{B}$ \\
\hline \multirow{2}{*}{ NI } & $\mathrm{h}$ & $\mathrm{A}^{*}$ & & $\mathrm{~W}^{* * *}$ & & & $\mathrm{~A}^{*}$ \\
\hline & 1 & & & & & & \\
\hline \multirow{2}{*}{ Ks } & $\mathrm{h}$ & & & & & & $A^{*}$ \\
\hline & 1 & & & & & $A^{*}$ & \\
\hline \multirow{2}{*}{ To } & $\mathrm{h}$ & & & & & $A^{*}$ & \\
\hline & 1 & & & & & & \\
\hline
\end{tabular}

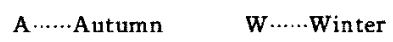

Table 6. Sex ratio in natural mating and artificial insemination

\begin{tabular}{|c|c|c|c|c|c|c|}
\hline \multirow{2}{*}{\multicolumn{2}{|c|}{$\begin{array}{l}\text { Exp. } \\
\text { station }\end{array}$}} & \multicolumn{2}{|c|}{ Nat. mat. } & \multicolumn{2}{|c|}{ Art. insem. } & \multirow{2}{*}{$\begin{array}{c}\text { Dif- } \\
\text { ference }\end{array}$} \\
\hline & & $8 \longdiv { 0 + 0 }$ & $\delta \%$ & $\delta+q$ & 今 $\%$ & \\
\hline \multirow{3}{*}{ NI } & & 13,065 & $51.5^{* * *}$ & 227 & $56.8^{*}$ & \\
\hline & $Y$ & 7,208 & 51.1 & 125 & $67.2^{* *}$ & ** \\
\hline & Hyb & 2,001 & 51.9 & 64 & 45.3 & $*$ \\
\hline \multicolumn{2}{|c|}{$\mathrm{Ks}$} & & & 4,538 & 50.9 & \\
\hline \multicolumn{2}{|c|}{ To } & & & 2,882 & $52.7^{* * *}$ & \\
\hline
\end{tabular}

らベかたよりを示す年令数は少ない，鹿児島では各年令 ともにかたよりを示さない，品種別好ると，畜試 Hyb の1年令，杤木Yの 2 年令で雄へかたよるが，他はかた よりを示さない.

8) 母ブタ年令別産子性比 (Table 8)：合計では，畜 試の $4 ， 7$ 年令，柘木の5 年令で雄へかたよるが，㢕児 島ではかたよりはみられない，品種別にみれば，畜試で はYの4，5，Bの4，7，Pと Hyb 02 年令で雄へ かたよっている，杤机で Y 5，LO3年令で雄人 かたよりを示す。
Table 7. Age of boar and sex ratio

Table 7-1. Age of boar and sex ratio in total of all groups of breed

\begin{tabular}{|c|c|c|c|c|}
\hline \multirow{2}{*}{ Age } & \multicolumn{2}{|c|}{ NI } & \multicolumn{2}{|c|}{ To } \\
\hline & $8+8$ & $8 \%$ & $8+q$ & $\widehat{\delta} \%$ \\
\hline 2 & & & 816 & $55.6 * *$ \\
\hline 3 & 1,973 & $52.3^{*}$ & & \\
\hline
\end{tabular}

Table 7-2. Age of boar showing a high or low sex ratio in each group of breed

\begin{tabular}{cccc}
\hline \hline Exp. & Sex ratio & $\mathrm{Y}$ & Hyb \\
station & $\left\{\begin{array}{c}\text { h } \\
\text { NI }\end{array}\right.$ & & \\
To $\left\{\begin{array}{c}\text { h } \\
\text { l }\end{array}\right.$ & $2^{* *}$ & \\
\hline
\end{tabular}

9）歴年度別産子性比 (Table 9)：今回の材料中第 II 大戦前の資料を含むのは畜試のみである. 合計では，雄 
へかたよる年度はみられるが、睢へかたよる年度はな い. 今回の 3 場では，かたよるのは 1 2 力年で，滝川 にくらべて少ない，品重別に双ると，滝川でかたより㞸 示さなかった Bに比較的多く，Yは漳川より少ない。 前報之同様に第项大戦前，中，後に区分して性比を比較 したが，有意の差はみられない，践後のみの鹿児島，枋 木の材料を加えても同様に有意差を示さない（表は省

Table 8. Age of sow and sex ratio

Table 8-1. Age of sow and sex ratio in total of all groups of breed

\begin{tabular}{|c|c|c|c|c|}
\hline \multirow{2}{*}{ Age } & \multicolumn{2}{|c|}{$\underbrace{N I}$} & \multicolumn{2}{|c|}{ To } \\
\hline & $6+9$ & $8 \%$ & $8+f$ & \% \% \\
\hline 4 & 1,232 & $55.4^{* * *}$ & & \\
\hline 5 & & & 180 & 58. $9^{*}$ \\
\hline 7 & 191 & $58.1^{*}$ & & \\
\hline
\end{tabular}

Table 8-2. Age of sow showing a high or low sex ratio in each group of breed

\begin{tabular}{|c|c|c|c|c|c|c|}
\hline $\begin{array}{l}\text { Exp. } \\
\text { station }\end{array}$ & $\begin{array}{c}\text { Sex } \\
\text { ratio }\end{array}$ & $\mathrm{Y}$ & $\mathrm{L}$ & B & $\mathbf{P}$ & Hyb \\
\hline $\mathrm{NI}$ & $\begin{array}{c}\mathrm{h} \\
1\end{array}$ & $4^{*}, 5^{* *}$ & & $4^{*}, 7^{*}$ & $2^{*}$ & $2^{*}$ \\
\hline To & $\begin{array}{l}\mathrm{h} \\
\mathrm{l}\end{array}$ & $5^{*}$ & $3^{*}$ & & & \\
\hline
\end{tabular}

Table 9, Annual sex ratio

Table 9-1. Calendar years showing a high or low sex ratio in total of all groups of breed

\begin{tabular}{|c|c|c|c|c|}
\hline \multicolumn{2}{|c|}{ Sex ratio } & \multirow{2}{*}{$\frac{N I}{131}$} & \multirow{2}{*}{$\frac{\mathrm{K}}{{ }^{\prime} 60,{ }^{\prime} 61}$} & \multirow{2}{*}{$\frac{\text { To }}{{ }^{\prime} 65}$} \\
\hline Hirh & 0.05 & & & \\
\hline $110 \mathrm{~g}$ & 0.01 & - & - & $' 67$ \\
\hline \multirow{2}{*}{ Low } & 0.05 & - & - & -- \\
\hline & 0.01 & - & - & - \\
\hline
\end{tabular}

略)、今回の筫料では，䋲川でみられたような，とくに 産子数の少ない年度は收られない，今回はカロリ一部算 は行なっていない

考察

文献的な考察は前報で行なったから，今回は潼川のデ 一夕との比較考察を主体にしたい。

1）総産子性比：合計で，鹿児島以外の各場とも雄へ かたよりながら4場の性比間には有意差がみら机ない。 よれは鹿児島も有意のかたよりではないが $50 \%$ をこえ ているためであろう．靯川の B 上，畜試，鹿児島の B の成績は異なる。このこと加ら，湆川Bの雌へのかたよ りは品㯝の特性とはいえない，Bの各場間の差をみる と，滰川と畜圾，庇児鼻間は有意である。このことは一 見地域差を示すようであるが，合計，Yでは有意差がみ これないことから，ブタでは地域差があるとはい光な い。また，㲘入配合飼料が多く使用される現状から， STOLKOWsKI（'67）の飼料組成による地域差も考克られ ない，Y，L，Bてみら机るよりが品種，䒺統，そ の他の原因比上るものか忧不明である。ショジウバ 工の性比について，性転換遺伝子（StuRTEVANT，"25 その他), 感染性と考光られる異常性比因子 (BuzzATITravarso '41 に始り, 本邦でも MoRIwaKI \& KITAgawa 5 '55, '57, IKEDA '65, 本㦔に䦔寸る Poulson \& SAKAGUCHI ら '61，'62，'63）が報告されている. 現在のとこ ろプタではこれら因子の存否は猚認できないが，念頭に おいて研究すべき事項であうう.

2）父，母ブタ個体と産子性此：産子性比のかたより を示す個体の出現をみるこ，Yに雄入かたよるものが多 、傾问がある。これはY はできない，滝川の父プタに産子性比が雄へかたよるも のが高率に出現したが，理由は不明である。

3）産次と産子性比：合計および産次群では，畜試の ものは滝川と同様に，ある範囲の産次では雄へがたよる といえ去うであるが，鹿児島，疗木での結果は異なり， また，品種別には，ほとえどYに集中している。これら

Table 9-2. Calendar years showing a high or low sex ratio in each group of breed

\begin{tabular}{|c|c|c|c|c|c|c|c|}
\hline $\begin{array}{c}\text { Exp. } \\
\text { station }\end{array}$ & $\begin{array}{c}\text { Sex } \\
\text { ratio } \\
\end{array}$ & W & $\mathbf{Y}$ & $\mathrm{L}$ & $\mathrm{B}$ & $\mathrm{P}$ & Hyb \\
\hline \multirow{2}{*}{ NI } & $\mathbf{h}$ & & $133^{*}$ & & $123^{*},{ }^{\prime} 34^{*},{ }^{\prime} 46^{*}$ & $27 *$ & ' $31^{*},{ }^{\prime} 32^{*},{ }^{\prime} 49^{*}$ \\
\hline & 1 & $151^{*}$ & & & & & \\
\hline \multirow{2}{*}{ Ks } & h & & & & ${ }^{\prime} 60^{*},{ }^{\prime} 61^{*}$ & & \\
\hline & 1 & & & & & & \\
\hline \multirow{2}{*}{ To } & $\mathrm{h}$ & & ${ }^{\prime} 65^{*}, ' 67^{*}$ & $' 66^{* *}$ & & & \\
\hline & 1 & & & & $\because$ & & \\
\hline
\end{tabular}




\section{西田・大挥・闲藤}

のことふらブタにおいて恃臛次と性比の関係について の絬訟は慎重を要する.

4）同腹子数と産子性比：令回の3場では，かたより を示寺子数区が少小く，また，子数区分，品種別の結果 も区々であるから，子数とともに性比が高をる(KING \& STOTSENBURG '15 $九 の$ 他) との説に対しては, 現在のと ころ筫成でない，鹿児島の B，Hyb は子数别では， 雄へかたより夌示寸区をもつが，卆の理由は不明であ b.

5）季斯と産子性比：合計では，今问の3場の結果は

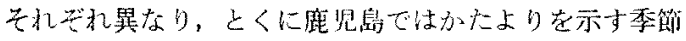

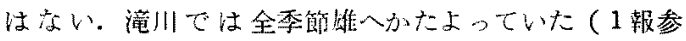
照),以上のことからブタでは 定の季節的かたよりは否 定される可能性が強い，品種別にみると，滝川で雌へか

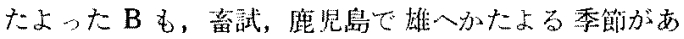
る.このことから滝川の比への季節的かたよりは, 品種 的特性ではなとい方る。系統的なものかどうかは，潼

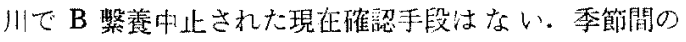
性比差に怙いて，籍一，二次で異なった結果を示し，場 により，品㮔によっても結果が異なるから，李笛と産子 性比に対する絬猃は下せない。

6）自然交配，人工授精乙産子性比：2㱠配法間の性 比差老双ると，合計では差はみられない。畜試の $\mathrm{Y}$ ， Hyb では差は有意であり，とくにYの人工授精では異 常に高いが，滝川のYでは差はなかった。これらのこと から，人工授精で性比が高くなるとの説には替成できな い. 畜試での伊藤ら（'48）以後のデー多を期待していた が，入千できなかったので，比較論及することはできな เ.

7）父，母ブタ年令と産此性比：父，母ブタとも， 合計では一見若壮年令で雄八かたるるが加えるが，咸 韭島ではかたよりがみられず，者た，品種別にみても結 果は区ヶであるから，結諭は慎重要要子る。畜試のB，

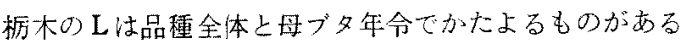
が，系ブ夕年令ではかたよりを示さないこのような全 体と父，母プタ年令とで異なった結果索すことの理由 は不明でる。

8）歴年度と産子性比：今回毛第而大戦前徯の性比の 変動は更ら㚘ないから，ブタでも大戦による性比の変動 はない上いってよいであるう。しかし，性比のかたより 定示す年度の存在する理由㳳明できない。

\section{要約}

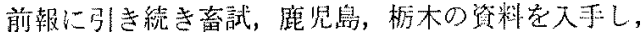
同栐流分析を行ない，滝川と比較して，次の結果を得た。

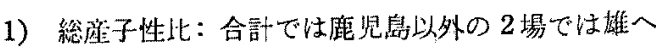
かたよる，品䅜别では，場により，品種によって結果は 区々である，場開の性比差をみると，合計，Yでは有意 庄はないが，しとBに打いては，潼川との間に有意差が みられる。

2）父，标ブタ個体別：父，母ブタとも，産子性比 のかたよりを示寸個体があるが，潼川にくらべやや少な

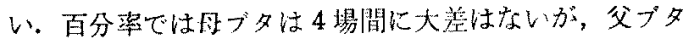
では滝川が明らかに高罢を示した。

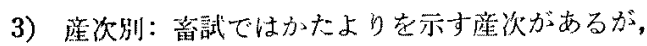
その数潼川よりやや少ない，杤机でもかたよる産次が みられるが，鹿児島ではかたよりはみられない，品種別 では，Yにかたより走示座次が最も多い。蓄試のBで

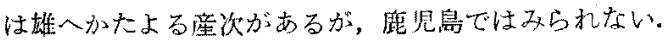

4）同腹子数別：合計，品種别ともにかたよりを示す 閔級の数は少ない，鹿児島では，BとHybでみられた かたよりは，合計ではかくされ，子数1で踓へかたよる。

5）季節別：季節の性此はかたよることもあるが，第 一，二次の合計，品種別乙もに，鼎によって結果は区ね

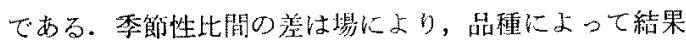
は区くである。

6）自然交配之人工授精：音㖶の合計では，有意差㤌 みられない，品種别で浩，Yと Hybで有意差がみら れる。

7）父，母ブタ年令別：合計では父，母ブタともに，

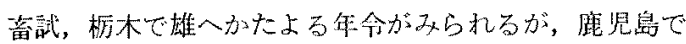
はみられない，品種别でも，鹿兒易ではみられない，品 種別のかたよりを西す年令の数は母プタが父ブタよりや p多い.

8）歴午度別：性此のかたよりを示寺のは，3場とる に1〜2力年度で，滝川より少ない，品種別にみると，

B に比較的多い，窐試のWで 1 年度だけ睢へかたよる のがみられる。第㞦大戦前後て性比に有意差はみられ ない.

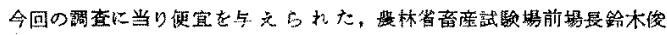

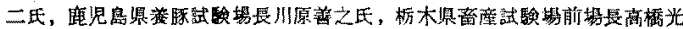

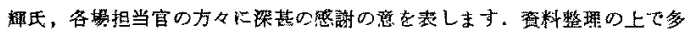

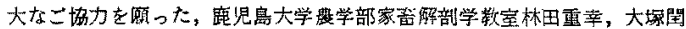

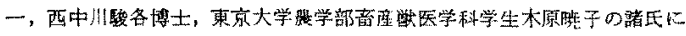
心かに怙札を中し上ばます。

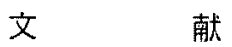

1) Buzzati-Trayerso, A.A. (1941) D.I.S., 14:49. (Moriwaki \& Kitagawa '57 そりり)

2) IKEDA, H. (1965) Sci., 147:1147. 
3）伊藤祐之・丹羽太左街門・工藤 䉥 (1948) 音 武報，（55）：57.

4) KIng, H.D. and J.M. Stotsenburg (1915) Anat. Rec., $9: 403$.

5) Kitagawa, O. and D. Moriwaki (1955) D.I.S., $29: 131$.

6) Moriwakl, D. and O. Kitagawa (1957) Jap. J. Genet., $32: 208$.

7）西田司一・方昜光一・瀬田季茂・大塚 順 - 首藤 新一・所 和啺 (1969) 日畜会報, $40: 449$.
8) Poulson, D.F. and B. Sakaguchi (1961) Sci., $133: 1489$.

9) SaKaguchi, B. and D. F. Poulson (1961) Genetics, $46: 1665$.

10) Sakaguchi, B. and D.F. Poulson (1963) ibid, $48: 841$.

11) StoLkowski, M. J. (1967) Comptes rendus, Sér. D., $265: 1059$.

12) Sturtivant, A.H. (1945) Genetics, $30: 297$.

\title{
Résumé
}

Sex ratio of offspring in domestic animals: Swrine (2)

\author{
Shiichi Nishida, Jun Otsuka ${ }^{1 \prime}$ and Kaoru SaIto ${ }^{2 \prime}$ \\ (1) Cobb Japan Farm, ${ }^{2}$ Tochigi Experiment Station of Animal Husbandry)
}

Data on sex ratio in swine were obtained from the National Institute of Animal Husbandry (NI), Kagoshima Swine Experiment Station (Ks), and Tochigi Experiment Station of Animal Husbandry ( $\mathrm{To}$ ), and compared with those obtained at Takikawa ( $\mathrm{Ta}$ ) mentioned in the preceding report (1). The animals used in the present study numbered 13,085 at NI, 4,538 at $\mathrm{Ks}$ and 2,882 at To (Ks and To: artificial insemination only). They consisted of Large White $(W)$, Yorkshire (Y), Landrace (L), Berkshire (B), Chinese Pig (C), Poland China (P), and their hybrids (Hyb) at NI and $\mathrm{B}, \mathrm{L}$ and $\mathrm{Hyb}$ at $\mathrm{Ks}$ and $\mathrm{Y}$ and $\mathrm{L}$ at To. Analysis on sex ratio was performed by the same methods as described in report (1). The results obtained are summarized as follows.

1) Total (Table 1): The sex ratio in all the groups of breed as a whole was high at NI and To. No shift in this ratio was seen at Ks. The sex ratio in each group of breed varied with the station and breed. There were no significant differences in sex ratio among four stations ( $\mathrm{Ta}, \mathrm{NI}, \mathrm{Ks}$, and $\mathrm{To}$ ) with regard to all the groups of breed. In $\mathrm{L}$ and $\mathrm{B}$, however, there were significant differences between $\mathrm{Ta}$ and $\mathrm{Ks}, \mathrm{Ta}$ and $\mathrm{NI}$, and $\mathrm{Ta}$ and $\mathrm{Ks}$.

2) Boar and sow (Table 2): In some cases, the sex ratio of offspring originated from an individual boar or sow showed a shift to either sex. These individuals, however, were fewer than those at $\mathrm{Ta}$. The same facts were also seen in respect to each breed. The percentage of these boars was apparently high at Ta. There were no significant differences, however, in the percentage of sows among four stations.

3) Litter series (Table 3): The sex ratio was significantly high in some orders and in some groups of order of parturition in all the groups of breed as a whole at NI and To, as well as at Ta. No significant shift was seen at Ks. The orders showing a shift in $\mathrm{Y}$ were more frequent than those in any other breed. Contrary to the results at Ta, B showed a shift to male in one order of parturition at NI. No shift was seen at Ks.

4) Litter size (Table 4): Results varied with station and breed in all the groups of breed as a whole and in grouping of litter size. In the present study, the class numbers of litter 


\section{西田・大域・槏藤}

size which showed a shift of sex ratio to either sex were smaller than those at Ta. Therefore, only from the results of the present study, the relationship between litter size and sex ratio cannot be explained clearly.

5) Seasonal change (Table 5): The primary and secondary sex ratio varied with station both in all the groups of breed as a whole and in each group of breed. The seasonal difference in sex ratio varied also with station. There was no significant difference in the present study, as shown between $\mathrm{B}$ and any other group of breed at Ta. Therefore, no conclusions can be drawn on the relationship between season and sex ratio before any further studies are carried out on this subject.

6) Natural mating and artificial insemination (Table 6): In the present study, the difference in sex ratio between natural mating and artificial insemination was insignificant in all the proups of breed as a whole at NI. Such difference was significant only in the $\mathrm{Y}$ and Hyb groups of breed at NI.

7) Age of boar and sow (Table 7 and 8): There were some age groups showing a shift of sex ratio to male, in all the groups of breed as a whole and in each group of breed, at NI and To. There was, however, no shift of sex ratio to either sex at Ks. The number of age groups showing a shift of sex ratio was smaller in boars than in sows.

8) Annual sex ratio (Table 9): A shift of sex ratio was seen in some years at the three stations in the present study. The number of these years was smaller than those at To. In the present study, these years were only one to two at each station. A shift of sex ratio to female was seen only in one year in W at NI. It was relatively frequent in B in these years. There was no significant difference in sex ratio among the three periods; that is, before, during, and after World War II. 